Original Paper http://ajol.info/index.php/ijbcs http://indexmedicus.afro.who.int

\title{
Contributions of soil chemical and physical properties in the dynamics of soil quality in the southern Cameroon plateau shifting agricultural landscape
}

\author{
Brunot NYECK ${ }^{1 *}$, Marguerite Ngo MBOGBA ${ }^{1,2}$, Isaac Konfor NJILAH ${ }^{1}$, \\ Martin YEMEFACK ${ }^{3}$ and Paul BILONG ${ }^{1}$
}

\footnotetext{
${ }^{1}$ University of Yaoundé I, Faculty of Science, Department of Earth Science, P.O. Box 812 Yaoundé, Cameroon.

${ }^{2}$ University of Maroua, Faculty of Science, Department of Earth Science, P.O. Box 814 Maroua, Cameroon.

${ }^{3}$ International Institute of Tropical Agriculture (IITA-Cameroon), P.O. Box 2008 Yaoundé, Cameroon.

*Corresponding author; E-mail: brunotnyeck@gmail.com; Tel: (+237)677198307
}

\begin{abstract}
Soil quality results from combination of chemical, physical and biological characteristics; according to ecosystems, some of these aspects become dominant. This Study was carried out on soils under 08 land cover types in the southern Cameroon ((bare soil with burned vegetation (FR1), bare soil with unburned vegetation (FR), Chromolaena odorata fallow (JC), bush ligneous fallow (JR), secondary forest (FS), primary forest (FC), Gilbertiodendron dewevei forest (FG), and raffia forest (RA) to assess the contributions of soil chemical and physical indicators into global soil quality index (IQSg). Topsoil samples were analyzed for physico-chemical characterizations and IQSg computed. Multiples statistical tests were used to compare the contribution of soil quality indicators and to select those that contributed the most in IQSg. Thus, under FR1, FC, FG and RA, IQSg was relatively high and the main contributors were chemical, estimated at more than $70 \%$. Under FR, IQSg remains high and chemical contribution predominant $(65 \%)$ on physical $(35 \%)$. On the contrary, under fallows, IQSg is relatively low; these two types of contributions are nearly equivalents. Thus, the main indicators helping to assess IQSg in lower cost, contributing significantly to global soil quality and representatives of indicators are: organic matter $(\mathrm{MO}), \mathrm{pHw}$, and $\mathrm{C} / \mathrm{N}$ ratio. The difference in contribution is due to the types of cultural practices, quality and quantity of MO brought by land cover types and topographical position.
\end{abstract}

(C) 2018 International Formulae Group. All rights reserved.

Keywords: Soil quality; land cover; shifting agriculture; south Cameroon.

\section{INTRODUCTION}

In the tropical slash and burn agriculture system, changes in the chemical properties of soil were much more evident and broader than changes in the physical properties (Edivaldo et al., 2014). At the beginning of the cropping period, soil chemical properties changed significantly due to the liming effect of ashes. This effect is more pronounced in older fallows prepared for cultivation than younger ones. Organic carbon and CEC (exchange cation capacity) are the chemical properties the least variable while the $\mathrm{pH}$, exchangeable bases and exchange acidity are the most variable (Nounamo et al., 2002; Yemefack, 2005). Aggregate stability was significantly lower after burning. Bulk density was not affected 
by clearing and burning at the beginning of cropping but somewhat higher at the end of two year cropping period (Yemefack, 2005). This latter acted indirectly on crop growth by influencing several other soil properties (permeability, water retention,...) that can individually or collectively impact directly on crop productivity (Douglas et al., 2003; Ali Ashraf Amirinejad et al., 2011). Owing to the poor status of ferrallitic soils, natural regeneration provided by MO from different land covers seems insufficient (Bilong et al., 2017); chemical contributions brought by organic manure (guano, and sheep) according to Biaou et al. (2017) improved significantly soil fertility. These soils characteristics or soil quality indicators can be divided into: inherent soil quality indicators when they reflected differences due to soil forming factors (climate, topography, parental material, time, ...); and processes and dynamic soil quality indicators, reflecting spatial or temporal changes depending on management history of soil resource (Douglas et al., 2003 ; Teklu et al., 2004 ; Bastida et al., 2008).

Several soil properties served as indicators of soil quality concerning productivity and sustainable management of soils. However, the challenge is to identify those which were more sensible or those which contributed significantly to the current functioning of soils identified under different land cover types, inherent from shifting agriculture. According to the type of agricultural system or to the type of soil management, several studies have been made (Andrews et al., 2002a,b ; Seyed et al., 2006 ; Mairura et al., 2007 ; Ping Li et al., 2012), identifying keys indicators in expression of soil quality and determine the characteristics (chemical, physical or biological) which are the predominant in the accomplishment of soil functions, precisely the main ones (production). However, under shifting agricultural system of South Cameroon plateau, such studies are still scare. Consequently, the platform for activities planning to upgrade these of soil basing on the knowledge of different indicators lacks enough useful and reliable data. This study appreciates the contribution of chemical and physical characteristics of soil in the IQSg under different land cover types. The specific objectives of this work were: (i) to compute global soil quality index that comes from soil chemical and physical indicators under each land cover types, (ii) to isolate the contribution of each type of indicator in global soil quality index of each class of soil, and (iii) to identify among data set, those with a significant contribution to the global soil quality of the site.

\section{MATERIALS AND METHODS}

\section{Study site and the research design}

The experiment was conducted at the Nsimi village in the Zoétélé subdivision in the South region of Cameroon (Figure 1). The area is located at $120 \mathrm{~km} \mathrm{SSE}$ of Yaoundé and $13 \mathrm{Km}$ of Zoétélé, between $3^{\circ} 07^{\prime}-3^{\circ} 15^{\prime} \mathrm{N}$ and $11^{\circ} 45^{\prime}-11^{\circ} 52^{\prime} \mathrm{E}$. The annual rainfall shows a bimodal distribution pattern, leading to two rainy seasons corresponding to two cropping periods (March-June and SeptemberNovember). The annual rainfall varies between 1400 and $1900 \mathrm{~mm}$ and the mean annual temperature is $24{ }^{\circ} \mathrm{C}$ (Santoir et Bopda, 1995).The area is an undulating landscape with altitudes ranging between 600 and $705 \mathrm{~m}$ (a.s.l).

Shifting cultivation is the main agricultural land use system practiced by small scale farmers, which results in a mosaic spatial landscape pattern where some portions of primary forests are replaced by annual food crop fields, perennial plantations (cocoa, oil palm or rubber) or diverse fallow cover types (Nyeck, 2005; Yemefack, 2005). Depending on the dominant plant species, homogeneous plots have been delimited. They correspond to different regrowth ages of vegetation and the local conditions of their reuse for agricultural purpose in area. Our research design included the following land cover types: bare soil with burned vegetation biomass (FR1), bare soil with unburned vegetation biomass (FR), Chromolaena odorata fallows (JC), Bush ligneous fallows (JR), secondary forest (FS), Gilbertiodendron dewevei forest (FG), raffia 
and uapaca forest (RA) and primary forest (FC). Their descriptions were given in Table 1.

In the field, direct observations of the physiognomy of land cover coupled with the identification of dominant plant species and interviews of local farmers helped to determine the cover types and their age ranges. Dominant soils across the area are acrisols and Ferralsols (WRB, 2006); they are acidic in the level of series (Adibime et al., 2016). They were located in the upper gently sloping valleys. Whereas few gleysoils or hydromophics soils occupy the swampy valleys. These soils are developed on pyroxene granites (Champetier de Ribes et Aubague, 1956). Composite soil samples were collected using an Edelman auger at $0-20 \mathrm{~cm}$ depth under each land cover type with three replications. These soil samples were air-dried before grinding and sieving, then, used for routine laboratory analyses.

\section{Soil sampling and chemical analyses}

Soil samples were analyzed at IITA (International Institute of Tropical Agriculture) laboratory of Nkolbisson (Cameroon) for the following: $\mathrm{pHw}$ in water, determined in suspension soil/water equal to 1 / 2.5 ratio. Exchangeable bases $(\mathrm{Ca}, \mathrm{Mg}, \mathrm{K})$, available $\mathrm{P}$ and $\mathrm{Fe}$ were extracted by the Mehlich-3 procedure (Mehlich, 1984). Exchangeable bases and $\mathrm{Fe}$ were determined by atomic adsorption spectrophotometry and, available $\mathrm{P}$ by Bray II procedure (Motomizu et al., 1983). Exchangeable Al was determined using $1 \mathrm{M} \mathrm{KCl}$ and extracted colorimetrically using pyrocatecol violet. Cation exchange capacity (CEC) was carried out using the ammonium acetate method at $\mathrm{pH} 7$ (Summer and Miller, 1996). Total $\mathrm{N}$ using the Kjeldahl method for digestion and ammonium electrode determination (Bremner and Tabatabai, 1976), organic carbon (OC) using chromic acid digestion and spectrophotometric analysis (Heanes, 1984), organic matter (MO) was obtained using conversion factors for surface horizons of 1.724 for soils under anthropogenic land cover types and 2.0 for soils under undisturbed land cover types (Nelson and Sommers, 1972).

\section{Physical soil analyses}

Physical parameters analysed included: particle size and bulk density determination. For bulk density, three core samples were taken under each land cover type, at $0 \pm 5$, $5 \pm 10$ and $10 \pm 15 \mathrm{~cm}$ depth. Cores were $5 \mathrm{~cm}$ long and had a volume of $100 \mathrm{~cm}^{3}$. They were obtained following the ratio weight of dry sample under his volume $(\mathrm{W} / \mathrm{V})$ before already subtract the weight of sampling bag. Soil particle size was determined by chemical dispersion using hexametaphosphate (soil:liquid ratio, 1:20, wt/wt). Looking at the correlation between different particle sizes (sand, clays and silt), strong negative correlations $(r=-99$ and $r=-0.70)$ were observed; respectively between sand and clay fractions on the one hand and between silt and clay fraction on the other hand. Moreover, silt fraction was found very low in the forest ferrallitic soils of South Cameroon (Yemefack et al., 2004). Therefore, clay fraction represents in this study sand and silt fraction in the assessment of soil physical quality.

\section{Computation of global soil quality index (IQSg)}

Soil quality index is a numerical value that can be used to monitor the long - term changes in soil quality (Fabrice et al., 2003). Its determination is done in three main steps: (1) a good selection of indicators that best represent soil function, (2) normalization of indicators or variables and determination of their proportional coefficients (scores), and (3) combination of the normalized data by their proportional coefficient to a product for each variable and summation of the product of variable gives the global soil quality index under each land cover type. Soil quality is determined by both inherent and dynamic properties and processes interacting within a living dynamic medium (Douglas et al., 2003; Teklu et al., 2004; Bastida et al., 2008). Monitoring soil quality is also important because, it provides a valuable base upon which subsequent and future measurements 
can be evaluated (Yanbing et al., 2009). In this study, soil chemical and physical indicators were used.

The indicators were chosen at first according to general approach which considers the available wide data set (Seyed et al., 2006; Yanbing et al., 2009). Then, the minimum data set is obtained on the basis of statistical analyses (Andrews et al., 2002; Fabrice et al., 2003; Yemefack et al., 2006; Yanbing et al., 2009). For data normalization, each value of indicator was divided by its standard deviation so that at the end, all the indicators received a standard deviation equal to 1 . For the determination of proportional coefficient, the method used is the linear scoring; here, the normalized value of each indicator are ranked in ascending or descending order depending on whether a higher value was considered "good" or "bad" in terms of soil function. For "more is better" indicators, each value of indicator was divided by the highest observed value (divisor) such that the highest observed value received a score of 1 and the remainder less than 1. For "less is better" indicators, the lowest observed value (numerator) was divided by each value of indicator (denominator) such that the lowest observed value received a score of 1 and the remainder less than 1 . The indicator scores vary between 0 and 1 . A score of 1 was given when an indicator value represented high soil function. A Combination of normalized value with their proportional coefficients give a product $\left(W_{i} X_{i}\right)$ and the sum of the products of indicators give global soil quality index (IQSg) under each land cover type according to the equation (1) described by Andrews et al. (2002).

$I Q S g=\sum_{i=1}^{n} W i X i(1)$.

Where $W$ is the normalized value of indicator; $X$ is the indicator score; IQSg is the global soil quality index without unit; $i$ is a soil property and $n$ the number of soil properties. Each soil sampled under a specific land cover type is characterized by it IQSg. High global soil quality index indicates better soil quality (Andrews et al., 2002, 2003). Doran et al. (1994) considered that the highest soil quality would correspond to natural undisturbed lands. Therefore, the soil will be of good quality when it IQSg will be equal or higher than that under primary forest (FC) and vice versa.

\section{Assessment of absolute and relative contributions of indicators in the global soil quality index}

Absolute contribution of soil quality indicator into global index represents WiXi product of each variable where $W i$ is normalized variable and $X i$ proportional coefficient of this variable. This product therefore represents the quality index of each variable or indicator. It is a product without unit.

Relative contribution expressed in percent (\%) was obtained according to the following equation: $\boldsymbol{x} \operatorname{cont}(\%)=\frac{\mathbf{I Q S i} * \mathbf{1 0 0}}{\mathbf{I Q S g}} \%$ (2) where $x \operatorname{cont}(\%)$ is the relative contribution of indicator; IQSi represents soil quality index resulting from a variable or indicator under a given type of land cover; i represents indicator or variable and IQSg global soil quality index resulting from all the indicators (chemical and physical soil quality indicators) under a given land cover type.

\section{Statistical analysis}

The 12 soil quality indicators under investigation were subjected to a descriptive statistical study using summary statistics. The analysis of variance (ANOVA) was performed to appreciate changes in chemical and physical contributions under different land cover types. The separation of means among the different land cover types was made using the least significant difference test at 0.05 probabilities (Tukey's test). Principal component analysis (ACP) was also used in order to select the indicator that contributed the most in the global soil quality of the site. These analyses were performed using STAT/SE version 11/0 (Statacorp LP, 2016) and XLSTAT 2007. 


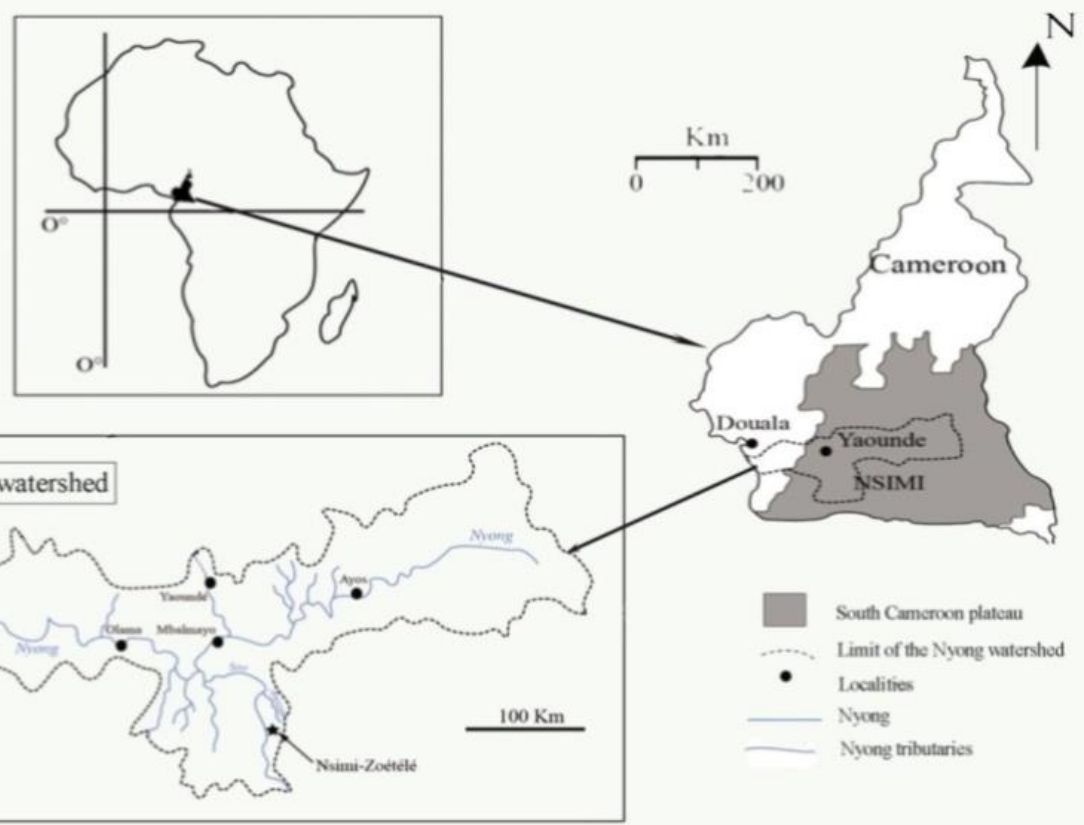

Figure 1: Localization of the Nsimi-Zoétélé watershed within the Nyong watershed.

Table 1: Descriptions of the main land cover types identify in the forest area of South Cameroon.

\begin{tabular}{|c|c|c|}
\hline $\begin{array}{l}\text { Land covers } \\
\text { types }\end{array}$ & age (year) & Physionomy \\
\hline FR1 & $\begin{array}{c}0(<3 \\
\text { months })\end{array}$ & $\begin{array}{l}\text { Clearing and burned plots with dry and burned abundant vegetal } \\
\text { biomass underground }\end{array}$ \\
\hline FR & $\begin{array}{c}0(<3 \\
\text { months })\end{array}$ & Clearing plots with abundant vegetal biomass dry underground \\
\hline $\mathrm{JC}$ & $2-5$ & Plots in majority covered by Chromolaena Odorata shrub species \\
\hline $\mathrm{JR}$ & $7-9$ & $\begin{array}{l}\text { Plots in majority covered by bush ligneous and some young } \\
\text { shrubs }\end{array}$ \\
\hline FS & $12-15$ & Plots covered by young shrubs and some forests species \\
\hline $\mathrm{FC}$ & $>50$ & $\begin{array}{l}\text { Plots covered by tropical forest species (Baillonella toxisperma, } \\
\text { Ceiba pantadia, Terminalia superba, Troplochiton) }\end{array}$ \\
\hline FG & $>50$ & Plot in majority covered by Gilbertiodendron Dewevei species \\
\hline RA & $>50$ & $\begin{array}{l}\text { Plots of swampy area colonized by raffia, Haumania } \\
\text { dankelmaniana }\end{array}$ \\
\hline
\end{tabular}

FR1: bare soil with burned vegetation biomass; FR: bare soil with unburned vegetation biomass; JC: Chromolaena Odorata fallow; JR: bush ligneous fallow; FS: secondary forest; FC: primary forest; FG: Gilbertiodendron Dewevei forest; RA:raffia and uapacca forest. 


\section{RESULTS}

\section{Summary statistics contributions of chemical and physical soil quality indicators}

Soil quality is determined under the basis of available indicators defining one or more given functions (Yanbing et al., 2009). Soil quality index (SQI) in the site differs in function of land cover type (Ngo Mbogba et al., 2015). The twelve indicators contributing to this difference are: $\mathrm{pHw}, \mathrm{MO}, \mathrm{CEC}, \mathrm{Ca}$, $\mathrm{Mg}, \mathrm{K}, \mathrm{C} / \mathrm{N}$ ratio, available $\mathrm{P}, \mathrm{Fe}, \mathrm{Al}$, clay particles and bulk density. Table 2 summarizes the statistics contributions of these indicators into global soil quality index under eight land cover types.

These contributions except of clay fractions showed a positive skewness with coefficient varying between 1.26 and 3.46. Significant contributions in global soil quality index were brought by $\mathrm{pHw}, \mathrm{C} / \mathrm{N}$ ratio, clay fraction, $\mathrm{CEC}, \mathrm{MO}, \mathrm{Ca}, \mathrm{Mg}$ and available $\mathrm{P}$. However, under soils with burned vegetation biomass (FR1) where global soil quality index was very high (35.35), significant contributions were due to $\mathrm{pHw}$ (9.17), Ca (4.34) and $\mathrm{Mg}$ (3.71). Under forest soils (FC, FG, RA) where global soil quality index meaningful higher, $(21.07,27.12$ and 28.66 respectively), the most important contributions were from $\mathrm{MO}, \mathrm{CEC}, \mathrm{C} / \mathrm{N}$ ratio and available $\mathrm{P}$. Under soils with unburned vegetation biomass (FR) which also presented high global soil quality index (25.98), main contributions were due to $\mathrm{pHw}(5.05), \mathrm{Mg}$ (1.70), C/N ratio (4.45) and clay fraction (2.91). On the contrary, soils under fallows (JC, JR, FS) presented a relatively low global soil quality index; 20.03, 19.26; 19.56 respectively. Here, clay fraction, $\mathrm{C} / \mathrm{N}$ ratio and $\mathrm{pHw}$ were the main contributors in IQSg (Figure 2). Contributions brought by $\mathrm{K}, \mathrm{Fe}$, and exchangeable $\mathrm{Al}$ were negligible; those generated by bulk density were important but did not help to discriminate soil according land cover types.

Soils with burned vegetation biomass (FR1) and forest covers (FC, FG, RA) contributions were essentially chemicals and representing $75 \%$ and $63 \%, 72 \%, 78 \%$ of global soil quality index respectively. Under soils with unburned vegetation biomass (FR), chemical indicators contributed for $65 \%$ and physical indicators for $35 \%$. The main indicators were clay fractions (physical indicator) with $11.20 \%$ and chemical indicators ( $\mathrm{pHw}, \mathrm{Mg}$ and $\mathrm{C} / \mathrm{N}$ ratio) for $43 \%$. Under fallow soils (JC, JR, FS) soil quality depends on chemical and physical indicators as well. Contributions were almost equivalent. Chemical indicators participated for $52 \%$ and physical indicators for $48 \%$ on the average. Main contributions were provided by $\mathrm{pHw}$ (18\%), C/N ratio (23\%) and clay fraction (14\%) (Figure 3).

Thus, chemical quality of soil was controlled by ash from burned vegetation biomass land cover type, and internal drainage linked to topographical position was predominate to the physical ones. Physical quality was conjointly controlled by hand ploughing (tillage) and topography. Therefore, chemical soil quality indicators determine global soil quality in the site.

\section{Variability of indicators contributions with land covers types}

The contribution of indicators significantly $(P=0.000)$ variable were subjected for the analyses of variances (ANOVA) and mean separations (Tukey's HSD). The results of ANOVA and means separations as presented in Table 3 shows highly significant differences of contributions from one land cover type to another.

Contributions of $\mathrm{pHw}$ and exchangeables bases $(\mathrm{Ca}, \mathrm{Mg})$ were significantly higher under bare soils with burned vegetation biomass (FR1) as compared to those under bare soils with unburned vegetation biomass (FR), under fallows (JC, JR, FS) and under forest soils (FC, FG, RA). Contributions of organic matter (MO) were also significantly higher under forest soils (FC, FG, RA) and involved higher contributions of CEC under FG and RA even higher contributions of available P under RA in the global soil quality index. Contributions of clay fraction in global soil quality were significantly higher under fallows, under soils 
with unburned vegetation biomass (FR) and under soils with burned vegetation biomass (FR1) as compared to soils under forest land cover types.

The affinities of soils modalities obtained under different land covers types were recorded in Table 4. Whatever soil quality indicator, we always notice affinity of soils under the three fallows which were gathered in the same modality. Contributions of basics cations $(\mathrm{Ca}, \mathrm{Mg}), \mathrm{MO}$ and $\mathrm{pHw}$ always discriminates soils under the two types of bare soils (FR1 and FR), even each type of land cover underlined. Contributions of available $\mathrm{P}$ are related to swampy areas which were particularly discriminated by $\mathrm{MO}, \mathrm{pHw}$, CEC, and clay fraction. Variability of this latter marked by topography distributed soils under different land cover types along the slope. Variability contributions of $\mathrm{C} / \mathrm{N}$ ratio which distinguished soils under FG had discriminated species characterizing land cover type and then quality of organic matter brought by this specie.

\section{Minimum data contributing most in the global soil quality}

Some parameters are more sensitive to changes related to management practices than others. These parameters contributed most to soil quality and must be integrated among data set which expresses soil functioning within this traditional system. For their selection, Principal Component analysis (PCA) was used (Yemefack et al., 2006; Yanbing et al., 2009; Ping Li et al., 2013). According to the procedure described by Andrews et al. (2002), only principal components (Pcs) with eigen values $\geq 1$ were considered for the minimum data set (MDS). For each PC, indicators receiving weighted loading value within $10 \%$ of the highest weighted loading were selected for the minimum data set. Soil chemical and physical indicators constitute the list of soil quality indicators contributing to global soil quality. Three principal components (PC1, PC2, PC3) had eigen values $\geq 1$ according to the method indicated above. These principal components explained more than $91 \%$ of variability of indicators contributions into IQSg (Table 5).

Highly weighted indicators for the first principal component (PC1) included: organic matter (MO), CEC, available $\mathrm{P}, \mathrm{Fe}$ and clay fraction. Correlation coefficients between these five indicators were well correlated (pearson coefficient correlation > 0.70). However, contributions of MO were most highly correlated and thus chosen for the minimum data as most representative of that group. For PC2, highly weighted indicators were $\mathrm{pHw}, \mathrm{Ca}$, and $\mathrm{Mg}$; they were well correlated. PC3 was represented by $\mathrm{K}$ and $\mathrm{C} / \mathrm{N}$ ratio, which were highly weighted indicators. Thus, $\mathrm{pHw}$ and $\mathrm{C} / \mathrm{N}$ ratio were the most highly correlated and thus chosen for the minimum data as most representative respectively of group 2 and group 3

Finally, indicators determining global soil quality index value and representatives of chemical and physical indicators in the site were: $\mathrm{MO}, \mathrm{pHw}$ and $\mathrm{C} / \mathrm{N}$ ratio. Under fallows (JC, JR and FS), there were no significant differences in the contributions of these indicators. They contributed for $43 \%$ in their global soil quality index. Under bare soils (FR1 and FR) and forest soils (FC, FG and RA) there were significant differences within contributions. Under bare soils with burned vegetation biomass (FR1), these indicators contributed for $44 \%$ in global soil quality index and $38 \%$ under bare soils with unburned vegetation biomass (FR). Under forest soils (FC, FG, and RA), they contributed for $43 \%$, $54 \%$ and $36 \%$ respectively (Figure 4 ). Capture of total variability of soil quality index by this minimum data set within the traditional landscape shifting cultivation helps to reduce considerably the cost of land evaluation by determining only the three soil indicators instead of twelve. 
Table 2: Summary statistics of absolutes contributions of indicators in the global soil quality index ( $\mathrm{n}=16$ composites samples).

\begin{tabular}{lccccccccccccc}
\hline Stats & MO & pHw & CEC & Ca & Mg & K & C/N & Bray P & Fe & Al & Clay & Dad & IQSg \\
\hline Mean & 0.89 & 3.98 & 1.41 & 0.40 & 0.59 & 0.38 & 5.00 & 0.98 & 1.18 & 0.01 & 2.19 & 6.25 & 23.27 \\
Max & 4.60 & 9.17 & 4.14 & 4.34 & 3.70 & 4.09 & 9.73 & 4.14 & 5.01 & 0.01 & 4.26 & 6.26 & 35.35 \\
Min & 0.13 & 2.85 & 0.22 & 0.00 & 0.01 & 0.01 & 3.37 & 0.18 & 0.19 & 0.01 & 0.07 & 6.25 & 19.26 \\
Sd & 1.12 & 1.54 & 1.28 & 1.06 & 1.09 & 1.03 & 1.56 & 1.16 & 1.16 & 0 & 1.11 & 0.00 & 5.44 \\
CV & 1.26 & 0.39 & 0.91 & 2.65 & 1.84 & 2.69 & 0.31 & 1.19 & 0.99 & 0 & 0.51 & 0.00 & 0.23 \\
Kurtosis & 8.77 & 9.21 & 3.24 & 13.3 & 6.37 & 12.0 & 6.38 & 4.99 & 8.56 & - & 2.82 & 6.14 & 3.14 \\
Range & 4.46 & 6.32 & 3.92 & 4.33 & 3.70 & 4.09 & 6.36 & 3.96 & 4.82 & 0 & 4.19 & 0.01 & 16.09 \\
skewness & 2.48 & 2.58 & 2.26 & 3.46 & 2.25 & 3.22 & 1.74 & 1.76 & 2.34 & - & -0.35 & 2.27 & 1.26 \\
\hline
\end{tabular}

Min: minimum; Max: maximum; Sd: standard deviation; CV: coefficient of variation; IQSg: global soil quality index; Dad: bulk density; CV: coefficient of variation; Sd: standard deviation; MO: organic matter.

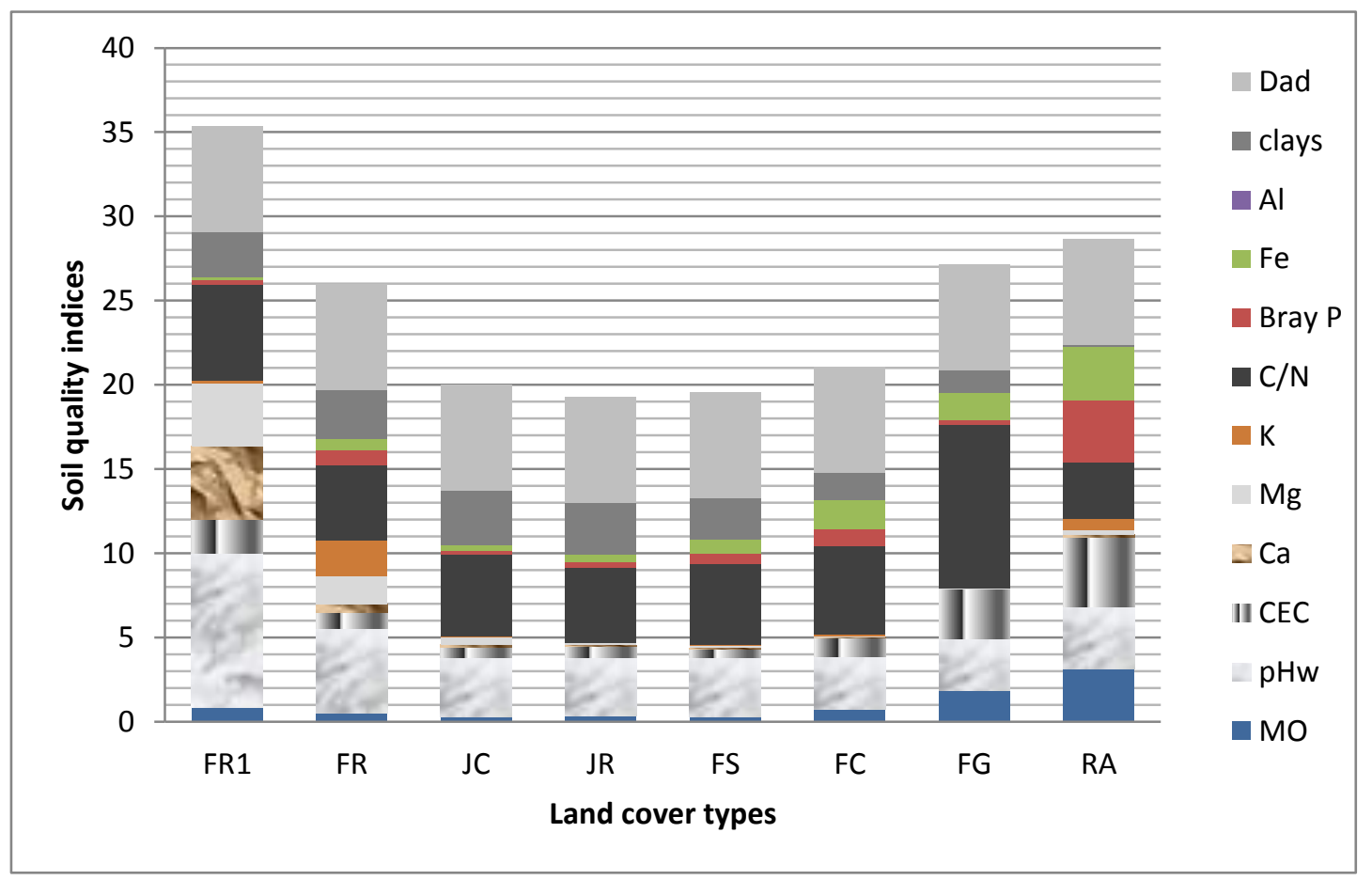

Figure 2: Absolutes contributions of soil quality indicators in the global soil quality index.

FR1: bare soil with burned vegetation biomass; FR: bare soil with unburned vegetation biomass; JC: Chromolaena odorata fallow; JR: bush ligneous fallow; FS: secondary forest; FC: primary forest; FG: Gilbertiodendron dewevei forest; RA:raffia and uapacca forest; Dad: bulk density; MO: organic matter 


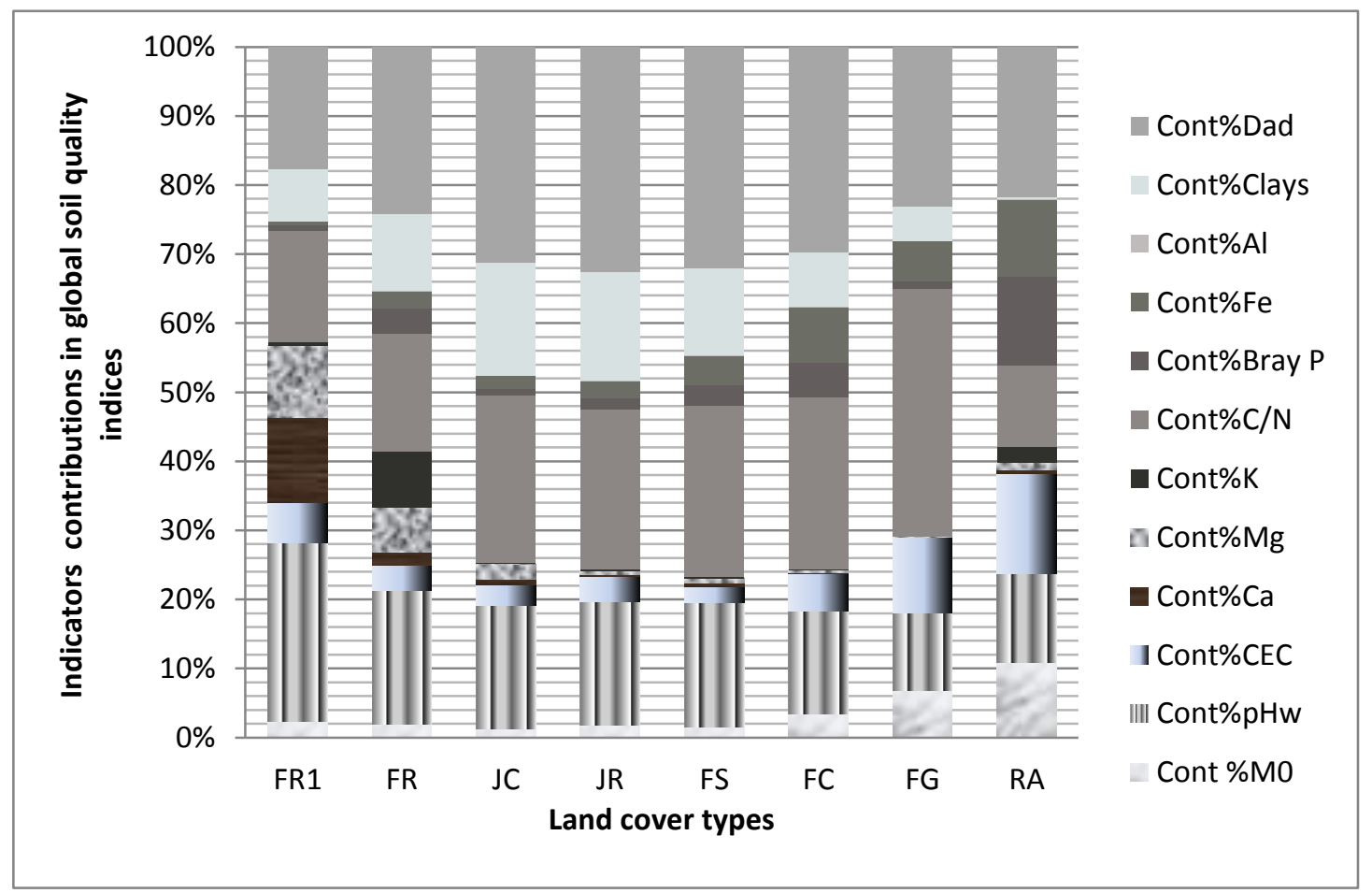

Figure 3: Relatives contributions of soil quality indicators in the global soil quality index (IQSg).

FR1: bare soil with burned vegetation biomass; FR: bare soil with unburned vegetation biomass; JC: Chromolaena odorata fallow; JR: bush ligneous fallow; FS: secondary forest; FC: primary forest; FG: Gilbertiodendron dewevei forest; RA:raffia and uapacca forest; Dad: bulk density; MO: organic matter, Cont \%: relative contributions of indicators.

Table 3: Comparison of soil quality indicators contributions under different land cover types $(\mathrm{n}=$ 16 samples).

\begin{tabular}{ccccccccc}
\hline $\begin{array}{c}\text { Land cover } \\
\text { types }\end{array}$ & MO & pHw & CEC & Ca & Mg & C/N & Bray P & Clays \\
\hline & $\mathrm{R}^{2}=0.74$ & $\mathrm{R}^{2}=0.97$ & $\mathrm{R}^{2}=0.95$ & $\mathrm{R} 2=0.99$ & $\mathrm{R} 2=0.88$ & $\mathrm{R} 2=0.88$ & $\mathrm{R} 2=0.89$ & $\mathrm{R} 2=0.84$ \\
& $\mathrm{P}=0.021$ & $\mathrm{P}=0.000$ & $\mathrm{P}=0.000$ & $\mathrm{P}=0.000$ & $\mathrm{P}=0.001$ & $\mathrm{P}=0.001$ & $\mathrm{P}=0.000$ & $\mathrm{P}=0.002$ \\
$\mathrm{FR} 1$ & $0.82 \mathrm{ab}$ & $9.17 \mathrm{a}$ & $2.03 \mathrm{bc}$ & $4.34 \mathrm{a}$ & $3.71 \mathrm{a}$ & $5.68 \mathrm{~b}$ & $0.27 \mathrm{~b}$ & $2.67 \mathrm{a}$ \\
$\mathrm{FR}$ & $0.50 \mathrm{~b}$ & $5.05 \mathrm{~b}$ & $0.94 \mathrm{~cd}$ & $0.47 \mathrm{~b}$ & $1.70 \mathrm{ab}$ & $4.45 \mathrm{~b}$ & $0.92 \mathrm{~b}$ & $2.91 \mathrm{a}$ \\
$\mathrm{JC}$ & $0.26 \mathrm{~b}$ & $3.57 \mathrm{bc}$ & $0.61 \mathrm{~d}$ & $0.14 \mathrm{bc}$ & $0.45 \mathrm{~b}$ & $4.84 \mathrm{~b}$ & $0.21 \mathrm{~b}$ & $3.26 \mathrm{a}$ \\
$\mathrm{JR}$ & $0.34 \mathrm{~b}$ & $3.44 \mathrm{c}$ & $0.71 \mathrm{~d}$ & $0.06 \mathrm{bc}$ & $0.11 \mathrm{~b}$ & $4.47 \mathrm{~b}$ & $0.29 \mathrm{~b}$ & $3.05 \mathrm{a}$ \\
$\mathrm{FS}$ & $0.30 \mathrm{~b}$ & $3.53 \mathrm{c}$ & $0.45 \mathrm{~d}$ & $0.10 \mathrm{bc}$ & $0.13 \mathrm{~b}$ & $4.85 \mathrm{~b}$ & $0.58 \mathrm{~b}$ & $2.48 \mathrm{a}$ \\
$\mathrm{FC}$ & $0.71 \mathrm{~b}$ & $3.14 \mathrm{c}$ & $1.13 \mathrm{~cd}$ & $0.04 \mathrm{c}$ & $0.09 \mathrm{~b}$ & $5.25 \mathrm{~b}$ & $1.05 \mathrm{~b}$ & $1.64 \mathrm{ab}$ \\
$\mathrm{FG}$ & $1.84 \mathrm{ab}$ & $3.07 \mathrm{c}$ & $2.98 \mathrm{ab}$ & $0.00 \mathrm{c}$ & $0.01 \mathrm{~b}$ & $9.73 \mathrm{a}$ & $0.29 \mathrm{~b}$ & $1.34 \mathrm{ab}$ \\
$\mathrm{RA}$ & $3.13 \mathrm{a}$ & $3.67 \mathrm{bc}$ & $4.14 \mathrm{a}$ & $0.15 \mathrm{bc}$ & $0.29 \mathrm{~b}$ & $3.38 \mathrm{~b}$ & $3.65 \mathrm{a}$ & $0.12 \mathrm{~b}$ \\
\hline
\end{tabular}

Values followed by the same letters are not statistically different $(\mathrm{p}<0.05)$ according to least significative difference (Tukey's test). MO: organic matter; $\mathrm{R}^{2}=$ coefficient of regression; FR1: bare soil with burned vegetation biomass; FR: bare soil with unburned vegetation biomass; JC: Chromolaena odorata fallow; JR: bush ligneous fallow; FS: secondary forest; FC: primary forest; FG: Gilbertiodendron dewevei forest; RA: raffia and uapacca forest. 
Table 4: Different associations of soils modalities under different land cover types by indicator.

\begin{tabular}{|c|c|c|c|c|c|c|c|}
\hline \multirow{2}{*}{$\begin{array}{l}\text { Indicators } \\
\text { MO }\end{array}$} & \multicolumn{7}{|c|}{$\begin{array}{l}\text { Associations of soils modalities under different land covers types } \\
\text { according to indicator contributions in the global soil quality }\end{array}$} \\
\hline & \multicolumn{2}{|l|}{ FG FR1 } & \multicolumn{2}{|c|}{$\begin{array}{l}\text { JC JR FS FC } \\
\text { FR }\end{array}$} & \multicolumn{3}{|c|}{ RA } \\
\hline pHw & FR1 & \multicolumn{2}{|l|}{$\mathrm{FR}$} & \multicolumn{2}{|c|}{$\begin{array}{lll}\text { JC JR FS } & \text { FC } & \text { FG }\end{array}$} & RA & \\
\hline CEC & FR1 & \multicolumn{2}{|c|}{ FR FC } & JC JR FS & FG & & RA \\
\hline $\mathbf{C a}$ & FR1 & \multicolumn{2}{|l|}{ FR } & \multicolumn{3}{|c|}{\begin{tabular}{lll|l} 
JC & JR & FS & FC FG \\
RA & & &
\end{tabular}} & \\
\hline Mg & FR1 & \multicolumn{2}{|l|}{ FR } & \multicolumn{4}{|c|}{ JC JR FS FC FG RA } \\
\hline $\mathrm{C} / \mathrm{N}$ ratio & \multicolumn{3}{|l|}{ FG } & \multicolumn{4}{|c|}{ FR1 FR JC JR FS FC RA } \\
\hline Available P & \multicolumn{3}{|c|}{$\begin{array}{llll}\text { FR1 } & \text { FR JC JR } & \text { FSFC } \\
\text { FG } & & & \end{array}$} & \multicolumn{4}{|l|}{ RA } \\
\hline Clay fraction \% & \multicolumn{3}{|c|}{ FR1 FR JC JR FS } & $\begin{array}{ll}\mathrm{FC} & \mathrm{FG} \\
\end{array}$ & & & \\
\hline
\end{tabular}

FR1: bare soil with burned vegetation biomass; FR: bare soil with unburned vegetation biomass; JC: Chromolaena odorata fallow; JR: bush ligneous fallow; FS: secondary forest; FC: primary forest; FG: Gilbertiodendron dewevei forest; RA: raffia and uapacca forest

Table 5: Results of Principal Component analyses of indicators contributions in soil quality under different land cover types.

\begin{tabular}{lllll}
\hline PCs & PC1 & PC2 & PC3 & PC4 \\
\hline Valeur propre & 4.741 & 2.826 & 1.587 & 0.732 \\
Variabilité (\%) & 47.407 & 28.258 & 15.871 & 7.317 \\
Pourcentage cumulé & 47.407 & 75.665 & 91.536 & 98.853 \\
Variables pondérées & & & & \\
MO (\%) & $\underline{\mathbf{0 . 9 0 1}}$ & 0.378 & 0.143 & 0.049 \\
pHw & -0.488 & $\underline{\mathbf{0 . 8 6 9}}$ & 0.030 & -0.064 \\
$\mathrm{CEC}(\mathrm{Cmol} / \mathrm{kg})$ & $\underline{0.789}$ & 0.519 & 0.271 & 0.084 \\
$\mathrm{Ca}(\mathrm{Cmol} / \mathrm{kg})$ & -0.458 & $\underline{0.847}$ & 0.192 & -0.181 \\
$\mathrm{Mg}(\mathrm{Cmol} / \mathrm{Kg})$ & -0.511 & $\underline{0.855}$ & -0.043 & 0.054 \\
$\mathrm{~K}(\mathrm{Cmol} / \mathrm{kg})$ & 0.014 & 0.283 & $\underline{-0.693}$ & $\underline{0.663}$ \\
$\mathrm{C} / \mathrm{N}$ & -0.024 & -0.077 & $\underline{\mathbf{0 . 8 7 9}}$ & 0.467 \\
Bray P $(\mathrm{ppm})$ & $\underline{0.853}$ & 0.278 & -0.415 & -0.149 \\
Fe (ppm) & $\underline{0.987}$ & 0.062 & -0.037 & -0.040 \\
Al (Cmol/kg) & 0.000 & 0.000 & 0.000 & 0.000 \\
Clays $(\%)$ & $\underline{\mathbf{0 . 9 4 5}}$ & -0.207 & -0.168 & 0.030 \\
Dad & 0.000 & 0.000 & 0.000 & 0.000
\end{tabular}

Pc: principal component; underlined factor loadings are considered highly weighted; Factor loadings in bold correspond to the indicators included in the MDS. 


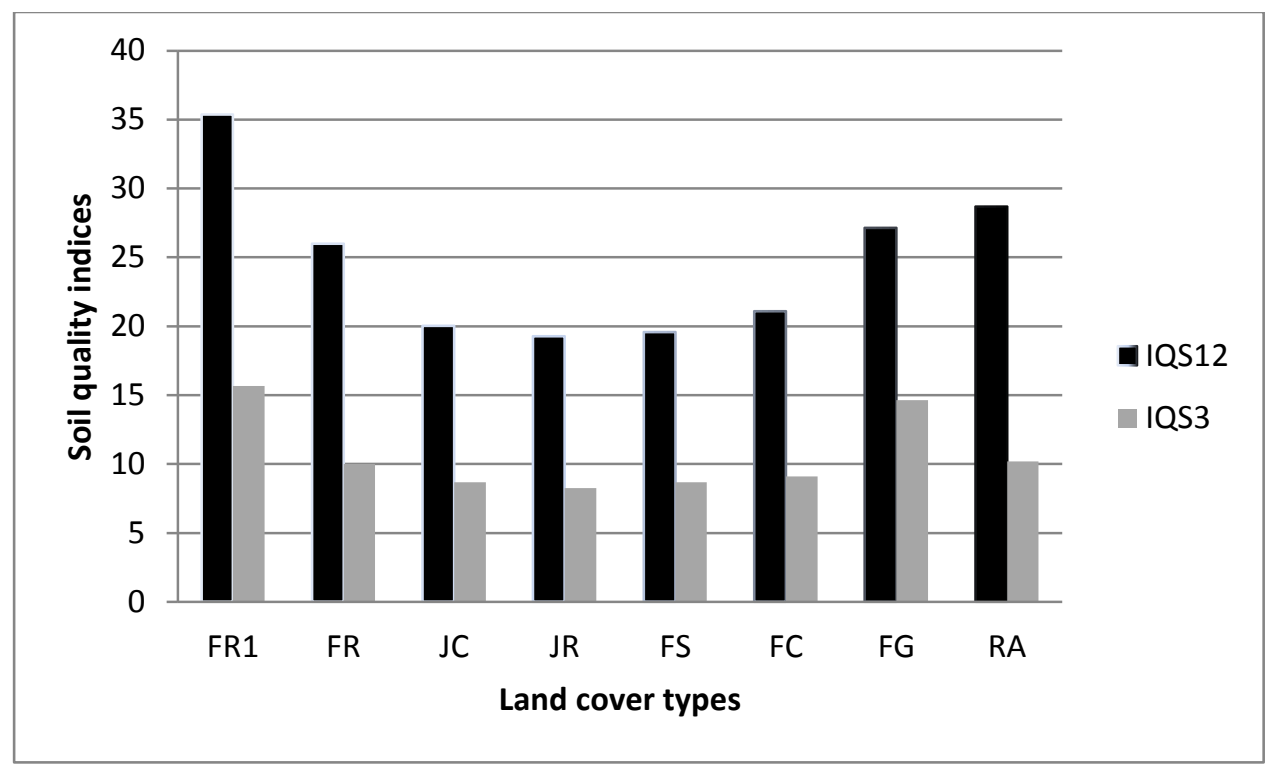

Figure 4: Representativeness of minimum data set contributions into global soil quality.

FR1: bare soil with burned vegetation biomass; FR: bare soil with unburned vegetation biomass; JC: Chromolaena odorata fallow; JR: bush ligneous fallow; FS: secondary forest; FC: primary forest; FG: Gilbertiodendron dewevei forest; RA:raffia and uapacca forest

\section{DISCUSSION}

Indicators contributions on soil chemical and physical quality

Significant contributions of chemical indicators ( $\mathrm{pHw}, \mathrm{Ca}, \mathrm{Mg}$ ) of soil with burned vegetation biomass (FR1) could be explained by ashes from burned vegetation biomass which had improved considerably soil pHw and consequently concentrations of basic cations $(\mathrm{Ca}, \mathrm{Mg})$. These effects of ashes were also observed by several authors (Nounamo et al., 2002; Yemefack, 2005) in plots of shifting agriculture in Center and South Cameroon and also by Tchatat et al. (2004) in the management of home gardens of the same area. Here, ashes from kitchen which were regularly thrown around homes improved soil quality by increasing $\mathrm{pH}$, concentration of exchangeable bases and by reducing exchange acidy. Under Forest soils (FC, FG, RA), main chemical contributions (MO, CEC, C/N, available $\mathrm{P}$ ) were due to i) high production of vegetal biomass which supply a higher content of organic matter (MO), ii) topographic position occupied by soils of swampy areas (FG, RA). Here, mineralization of MO was very low (Miralles et al., 2009) because of higher humidity and anaerobic conditions. Higher correlations observed between $\mathrm{MO}$ and several indicators (CEC; $\mathrm{r}=$ 0.86; available $\mathrm{P} ; \mathrm{r}=0.83$ ) suggest that their fluctuations remained under control of MO. Under soils with unburned vegetation (FR) and fallows (JC, JR, FS) chemical contributions of indicators could be explained by: i) differential inputs of MO by different land cover under which rapid mineralization of MO, favored by climate and drainage (soils from upper valleys) involve release of nutrient elements and ii) light post positive burned effects of ash that would continue to act some years latter under fallows (JC, JR, FS). The evidence of this post burn effect was brought by fragment of charcoals found while ploughing soils under fallows for seeding. Significant contribution of clay fraction under fallows could be due on one hand to the hand plough or tillage (with hoe) which has 
homogenized cultural profile by mixing deeper mineral horizons with surface organomineral horizons; on the other hand, the topographical position of these soils (upper valleys) relatively to those under forest (FC, FG, RA) (downstream) favour their enrichment in this fraction. Lateral drainage responsible of nutrient lixiviation could be less active than downstream under forest (FC, FG, RA). Furthermore under FG, the quality of organic matter supply to soils by Gilbertiodendron dewevei species was potentially rich in free fulvic acid fraction (Ngo Mbogba, 2008). This fraction might be responsible of impoverishment of basic cations and then subsequent enrichment of exchangeable Al. According to Temgoua et al. (2017), MO provided by Gilbertiodendron dewevei species is of mediocre quality $(\mathrm{C} / \mathrm{N}$ ratio $>10$ ). Thus, beside influence of ashes, land cover types on soil quality, pedogenetic evolution of catena as underlined by Nyeck (2005) in the characterization of poral space was marked by impoverishment of soils in clay fraction and bases from upstream to downstream. Therefore, differentiation of clay fraction in the soil depend on one soil forming factor which is topography, this physical property is qualify as inherent soil property. Likewise, the low contributions of basic elements $(\mathrm{Ca}, \mathrm{Mg}, \mathrm{K})$ under forest soils was confirmed by their topographical position where proximity with ground water indicated by Nyeck (2005) accentuates their desaturation favoring their enrichment in exchangeable Al.

\section{Minimum data set contributing into IQSg}

Ideally, a more balance data set has to include soil biological properties. However, these indicators selected $(\mathrm{MO}, \mathrm{pHw}, \mathrm{C} / \mathrm{N}$ ratio) for the minimum data set contributed to one or more soil functions as proposed by Doran and Parkin (1996) and participated more to global soil quality index value. Two of them were similar to those retained by Yemefack et al. (2006). They were affected by agricultural practices (Yemefack et al., 2006; Ping Li et al., 2012). Soil pHw was most sensitive to land management and easily to manage even at the village level (Tchatat et al., 2004). Its contribution in soils identified under different land cover types was manifested on humification and mineralization processes; since it directly acted in biological activity and availability of nutrient elements. It also indirectly acted on some soil physical properties (structure). C/N ratio which was low $(<25)$ in the whole soils is an indicator which informed on the evolution of soil organic matter and then the rate of release of nutrient elements; it was therefore excellent upon the whole soils (Temgoua et al., 2017). Finally, soil organic matter is an indicator of high importance and even fundamental in the definition of soil quality; since it controlled at same time chemical, physical (Bilong et al., 2017) and biological aspects which governed soil fertility (Kanmegne et al., 2004). Moreover, here soils of the forest area were poor in nutrient elements (Yemefack, 2005); because surface horizons were weakly influenced by geological substratum (more than $35 \mathrm{~m}$ depth below) (Nyeck, 2005), their agronomic quality depends mainly on organic matter decomposition to maintain their fertility.

These three indicators, despite their chemical nature, gave an account of global soil quality and are representatives of both physical and biological soil quality indicators. Directly or indirectly, it influenced physical (porosity, structure,...) and biological (humification and mineralization processes of organic matter) soil functions. Thus, representative chemical, physical and biological aspects and capturing total variability of soil quality index in this traditional shifting cultivation system, this minimum data set, help considerably to reduce land evaluation cost by determining only the three indicators instead of twelve.

\section{Conclusion}

This study aimed at appreciating and measuring contributions of soil chemical and physical indicators in the global soil quality identified under different land cover types within shifting agricultural landscape of South Cameroon. Chemical and physical 
contributions of soil quality indicators mainly differ according to land cover type and soil internal drainage due to topographical position. Thus, bare soil with burned vegetation biomass (FR1) and soils under forest had high global soil quality index; indicators contributing in their global soil quality were chemicals. Specially, $\mathrm{pHw}, \mathrm{Ca}$ and $\mathrm{Mg}$ were contributed under FR1; MO, $\mathrm{CEC}, \mathrm{C} / \mathrm{N}$ ratio and available $\mathrm{P}$ under forest land cover. Under soils with unburned vegetation biomass (FR) where global soil quality index was still high, contributions were both chemical and physical; soil quality indicators were $\mathrm{pHw}, \mathrm{Mg}, \mathrm{C} / \mathrm{N}$ ratio and clay fraction. Under fallows (JC, JR and FS), global soil quality index was relatively low; both chemical and physical indicators contributed. They were clay fraction, $\mathrm{C} / \mathrm{N}$ ratio, and pHw. These differences in contributions were due to: ashes from burned vegetation biomass (FR1), quantity and quality of soil organic matter supply by forest land cover, traditional ploughing or tillage (JC, JR and FS) and topographical position favorable to soils of upstream. Minimum data set allowing land evaluation at lower cost and contributing most in the global soil quality index whatever land cover type was summarized to three indicators: $\mathrm{MO}, \mathrm{pHw}$ and $\mathrm{C} / \mathrm{N}$ ratio. These indicators were representative of available wide data set and influenced directly or indirectly physical and biological soil functions of different soils.

\section{COMPETING INTERESTS}

The authors declare that they have no competing interests.

\section{AUTHOR'S CONTRIBUTIONS}

NB Participated in definition of the problem and framework of the study, supervision of sampling on the field and reviewed the manuscript. NMM participated for Sampling on the field, followed up laboratory analysis, compiling data, conceived and reviewed the manuscript. NIK has reviewed the manuscript. BP has defined the problem and reviewed the manuscript. YM has achieved Statistical analysis of data and reviewed the manuscript.

\section{ACKNOWLEDGEMENTS}

We are grateful to Nanchi from the Higher Institute of the Sahel from the University of Maroua for the helpful English language correction. We thank the anonymous reviewers for their critical and constructive comments, which helped to bring the manuscript to its current form.

\section{REFERENCES}

Adibime Onana A, Mvondo Ze AD, Yerima BP, Agoume V. 2016. Comparison of different phosphorous adsorption models in acid forest soils of Bityili (Southern Cameroon) and their relationship with soil properties. Int. J. Biol. Chem. Sci., 10(2): $\quad 820-834 . \quad$ DOI: http://dx.doi.org/10.4314/ijbcs.v10i2.30

Ali Ashraf Amirinejad, Kalpana Kamble, Pramila Aggarwal, Debashis Chakraborty,

Sanatan Pradhan, Raj Bala Mittal. 2011. Assessment and mapping of spatial variation of soil physical health in a farm. Geoderma 160: 292 - 303. DOI: 10.1016/j.geoderma.2010.09.021

Andrews SS, Flora CB, Mitchell JP, Karlen D L. 2003. Growers' perceptions and acceptance of soil quality indices. Geoderma 114: 187 - 213. DOI: https://doi.org/10.1016/S00167061(03)00041-7

Andrews SS, Karlen DL, Mitchell JP. 2002. A comparison of soil quality indexing methods for vegetable production systems in Northern California. Agriculture, Ecosystems and Environment 90: 25- $45 . \quad$ DOI: https://doi.org/10.1016/S01678809(01)00174-8

Andrews SS, Mitchell JP, Mancinelli R, Karlen DL, Hartz TK, Horwath W R, Pettygrove SG, Kate MS, Munk SD. 2002. On-Farm Assessment of soil quality in California's Central Valley. Agronomy Journal, 94: 12- 23. DOI: 10.2134/agronj2002.1200 
Bastida F, ZsolnayA, Hernández T, García C. 2008. Past, present and future of soil quality indices: A biological perspective. Geoderma 147: 159-171. DOI: 10.1016/j.geoderma.2008.08.007

Biaou ODB, Saidou A, Bachabi F-X, Padounou GE, Balogoun I. 2017. Effet de l'apport de différents types d'engrais organiques sur la fertilité du sol et la production de la carotte (Daucus carota L.) sur sol ferralitique au sud Bénin. Int. J. Biol. Chem. Sci. 11(5): 2315-2326. DOI https://dx.doi.org/10.4314/ijbcs.v11i5.29

Bilong EG, Ngome Ajebesone F, Abossolo Angue M, Birang à Madong, Ndaka Bonguen SM, Bilong P. 2017. Effets des biomasses vertes de Tithonia diversifolia et des engrais minéraux sur la croissance, le développement et le rendement du manioc (Manihot esculenta Crantz) en zone forestière du Cameroun. Int. J. Biol. Chem. Sci. 11(4): 1716-1726. DOI: http://dx.doi.org/10.4314/ijbcs.v11i4.24

Bremner JM, Tabatabai 1972. Use of an ammonia electrode for determination of ammonium in Kjeldahl. Analysis 3 :159165.

Champetier de Ribes G, Aubague M. 1956. Carte géologique de reconnaissance à l'échelle de

Douglas L, Karlen C, Ditzler A, Andrews SS. 2003. Soil quality: why and how? Geoderma 114: 145 - 156. DOI: 10.1016/S0016-7061(03)00039-9

Edivaldo L, Thomaz VA, Doerr SH. 2014. Effect of fire on the physicochemical properties of soil in a slash - and - burn agriculture. Catena 122: 209 - 215. DOI: http://dx.doi.org/10.1016/j.catena.2014.0 6.016

Fabrice C, Singer M J, Lindert P. 2003. A 60 - year history of California soil quality using paired samples. Geoderma 114: 215 - 230. DOI: 10.1016/S00167061(03)00042-9

Heanes DL. 1984. Determination of total C in soils by an improved chromic acid digestion and spectrometric procedure.
Communications in Soil Science and Plant Analysis 15: 1191- 1213.

Kanmegne J. 2004. Slash and burn agriculture in the humid forest zone of southern Cameroon: soil quality dynamics, improved fallow, management and farmer's perception. PhD. Thesis, Wageningen University. 184p + annexes.

Mairura FS, Mugendi DN, Mwanje JI, Ramisch JJ, Mbugua PK, Chianu JN. 2007. Integrating scientific and farmer's evaluation of soil quality indicators in Central Kenya. Geoderma 139: 134 143.

DOI:10.1016/j.geoderma.2007.01.019

Mehlich NW. 1984. Mehlich 3 soil test extractant: a modification of the Mehlich 2 extractant. Communications in Soil Science and Plant Analysis 15: 14091416.

Miralles I, Ortega R, Gonzalo A, Sanchez MM, Soriano M. 2009. Soil quality and organic carbon ratio in mountain agroecosystems of South east Spain. Geoderma 150: 120 - 128. DOI: 10.1016/j.geoderma.2009.01.011

Nelson DW, Sommers L. 1972. A simple digestion procedure for estimation of ammonium in Kjeldahl soils. Journal of Environmental Quality 1 : 423-425.

Ngo Mbogba M. 2008. Influence du type de végétation sur la qualité des sols dans le bassin versant de Nsimi - Zoétélé dans le plateau Sud camerounais forestier. Mém. DEA, Fac; Sci. univ. Ydé I, 68p + annexes.

Ngo Mbogba M, Yemefack M, Nyeck B. 2015. Assessing soil quality under different land cover types within shifting agriculture in South Cameroon. Soil and tillage research 150: 124 - 131. DOI: http://dx.doi.org/10.1016/j.still.2015.01. 007

Nounamo L, Yemefack M, Tchienkoua M, Njomgang R. 2002. Impact of fallow duration on topsoils characteristics of a ferralsol of southern Cameroon. Nig. J. soil Research $3: 52$ - 57.

Nyeck B. 2005. Organisation de la couverture ferrallitique du bassin versant de Nsimi- 
Zoétélé dans le plateau Sud Camerounais forestier d'Afrique Central: rôle de l'espace poral et de la dynamique hydrique dans sa transformation. Thès. Doct., Univ. Ydé I, Cameroun. $436 \mathrm{p}+$ annexes.

Ping Li, Taolin Z, Xingxiang W, Dongshen Y. 2012. Development of biological soil quality indicator system for subtropical China. Soil and tillage research 126: 112-118.

DOI: http://dx.doi.org/10.1016/j.still.2012.07. 011

Santoir C, Bopda A. 1995. Atlas regional Sud-Cameroun. (ORSTOM: Paris).

Seyed A R, Gilkes R J, Andrews SS. 2006. A minimum data set for assessing soil quality in rangelands. Geoderma 136: $229 \quad-\quad 234 . \quad$ DOI: 10.1016/j.geoderma.2006.03.021

Tchatat M, Ambassa - kiki R, Mbilla D and Fabre A. 2004. Assessing soil chemical fertility in home gardens in forested areas of Southern Cameroon. African Crop Science Journal, 12: 163 - 170.

Teklu E, Karl S and Gauser T. 2004. Participatory soil quality assessment: the case of smallholder farmers in Ethiopian highlands. Australian Journal of soil Research 42: 793-797. Short communication.

Temgoua E, Ntangmo Tsafack H, Ngnikam E, Raoul Takuete Gouana $\mathrm{R}$ et Zena Dongmo GR. 2017. Fertilisation du maïs (Zea mays L.) à base d'urines humaines hygiénisées dans un oxisol de l'Ouest Cameroun. Int. J. Biol. Chem. Sci., 11(5): 2071-2081. DOI : https://dx.doi.org/10.4314/ijbcs.v11i5.11

Yanbing Q, Darilek J L, Huang B, Yongcun Z, Weixia S, Zhiquan G. 2009. Evaluating soil quality indices in an agricultural region of Jiangsu Province,
China. Geoderma 149: 325 - 334. DOI: 10.1016/j.geoderma.2008.12.015

Yemefack M, Nounamo L, Njomgang R, Bilong P. 2002. Effect of natural fallow on topsoil properties and subsequent crop yields in forest Oxisol of Southern Cameroon. 17 $7^{\text {th }}$ WCSS, 14- 21 August, Thailand, Symposium $\mathrm{n}^{\circ} .13$, paper $\mathrm{n}^{\circ} .445$.

Yemefack M, Nounamo L, Njomgang $R$ et Bilong P. 2004. Influence des pratiques agricoles sur la teneur en argile et autres propriétés agronomiques d'un sol ferrallitique au sud Cameroun. Tropicultura, 22(1): 3-10.

Yemefack M. 2005. Modelling and monitoring soil and land use dynamics within shifting agricultural landscape mosaic system. PhD Dissertation Utrecht University. $190 \mathrm{p}+$ annexes.

Yemefack M, Jetten VG, Rossiter DG. 2006a. Developing a minimum data set for characterizing soil dynamics in shifting cultivation systems. Soil and Tillage Research, 86: 84-98. DOI: 10.1016/j.still.2005.02.017

Yemefack M, Rossiter DG, and Jetten VG, 2006b. Empirical modelling of soil dynamics along a chronosequence of shifting cultivation systems in southern Cameroon. Geoderma, 133: 380-397.

Zornoza RJ, Mataix S, Guerrero CV, Arcenegui AM, Mayoral J, Morales J, Mataix B. 2007. Soil properties under natural forest in the Alicante province of Spain. Geoderma, 142: 334-341. DOI: 10.1016/j.geoderma.2007.09.002 